https://doi.org/10.32689/2618-0065-2020-3(5)-120-131

Ковальов Ігор Вікторович, кандидат військових наук, доцент, Національна академія Національної гвардії України, 61001, м. Харків, майдан Захисників України, 3, тел.: 067-732-29-29, e-mail: kovalevigor309@gmail.com, http://orcid.org/0000-0002-7359-5776.

Волобусв Роман Васильович, старший викладач, Національна академія Національної гвардії України, 61001, м. Харків, майдан Захисників України, 3, тел.: volobueff.roman2240@ukr.net,http://orcid.org/0000-0002-4291-8093.

\title{
МЕХАНІЗМ СИНТЕЗУ ІНФОРМАЦІЙНО- АНАЛІТИЧНОГО ЗАБЕЗПЕЧЕННЯ НАЦІОНАЛЬНОЇ ГВАРДІЇ УКРАЇНИ В УМОВАХ НАДЗВИЧАЙНИХ СИТУАЦІЙ
}

Анотація. В статті розглянута система інформаційно-аналітичного забезпечення угруповання Національної гвардії України в умовах надзвичайної ситуації. Проаналізовані показники повноти, достовірності й оперативності інформації, що надходить від різних джерел у ході участі угруповань Національної гвардії України за призначенням в умовах надзвичайної стану ситуації спільно з іншими правоохоронними органами. Існування протиріччя між зростаючими потребами Національної гвардії України в інформації та нездатністю існуючої системи інформаційноаналітичного забезпечення надати інформацію з необхідною якістю свідчить про актуальність пошуку шляхів адаптації структури та побудови системи відповідно до потреб інформаційно-аналітичного забезпечення угруповань Національної гвардії України при виконанні завдань за призначенням спільно 3 іншими правоохоронними органами. Запропоновано підходи до отримання службової інформації, необхідної для управлінської діяльності; визначено вимоги до інформації, що підлягає аналізу в органах управління. Запропоновано підходи щодо синтезу раціональної структури системи інформаційно-аналітичного забезпечення, яка відповідає вимогам необхідної повноти надходження інформації до відповідних органів управління Національної гвардії України, але не перевантажує їх. Застосовано метод синтезу структури інформаційно-аналітичної системи 3 використанням алгебри моделей інформаційних структур та таксономічний метод, що дає можливість визначити раціональний варіант структури системи серед усіх вибраних.

Ключові слова: інформаційно-аналітичне забезпечення, структура системи, угруповання Національної гвардії України. 
Kovalov Ihor Viktorvich, Candidate of Science, Associate Professor, National Academy of National Guard of Ukraine, Kharkiv city,sq. Zakhysnykiv Ukrainy, 3, tel.: 067-732-29-29, e-mail: kovalevigor309@ gmail.com, http://orcid.org/0000-0002-7359-5776.

Volobuiev Roman Vasylovych, senior lecturer of the department of tactical and special training, National Academy of National Guard of Ukraine, Kharkiv city, sq. Zakhysnykiv Ukrainy, 3, tel.: 050-594-732-28,e-mail: volobueff.roman2240@ukr.net, http://orcid.org/0000-0002-4291-8093.

\title{
MECHANISM OF SYNTHESIS OF EMERGENCY INFORMATION AND ANALYTICAL SUPPORT OF THE NATIONAL GUARD OF UKRAINE
}

\begin{abstract}
The article discusses the system, which in a state of emergency is necessary for information and analytical support groups of the National Guard of Ukraine. The indicators of completeness, reliability and efficiency of information received from various sources during the participation of the groups of the National Guard of Ukraine for their intended purpose in a state of emergency together with other law enforcement agencies are analyzed. The existence of a contradiction between the growing needs of the National Guard of Ukraine for information and the inability of the existing system of information and analytical support to provide information on the necessary quality. This indicates the relevance of the search for ways to adapt the structure and build the system in accordance with the needs of information and analytical support of the groups of the National Guard of Ukraine in carrying out the assignment together with other law enforcement agencies. Construction during the performance of combat missions of the information and analytical support system law enforcement agencies, approaches to obtaining official information necessary for managerial activities are proposed; requirements for information to be analyzed in governing bodies are defined. Approaches to the synthesis of the rational structure of the information and analytical support system are proposed, which meets the requirements for the necessary completeness of the information received in the relevant governing bodies of the National Guard of Ukraine, but does not overload them with redundancy, determining the rational structure of the information and analytical support system. The result of the application of the methodology is the synthesized rational in the desired sense structure of the information and analytical support system groups of the National Guard of Ukraine while ensuring the fulfillment of tasks as intended. The method of synthesizing the structure of the information and analytical system using the algebra of models of information structures and the taxonomic method, which makes it possible to determine a rational version of the structure of the system among all the selected, are applied.
\end{abstract}


Keywords: information and analytical support, system structure, groups of the National Guard of Ukraine.

Постановка проблеми. На сьогодні своєчасне одержання достовірної інформації, іiі швидкий аналіз і зручне для користування подання результатів стали найважливішими передумовами успішного управління та виконання поставлених завдань за призначенням. Керівними документами, що регламентують діяльність Національної гвардії України (НГУ) передбачено: розвиток інформаційно-аналітичної діяльності у напрямку вдосконалення інформаційного забезпечення Головного управління, оперативно територіальних об'єднань, з'єднань, військових частин і підрозділів НГУ під час виконання завдань; відповідними програмними продуктами; створення необхідних мереж передачі даних між органами управління.

Слід зауважити, що інформаційно-аналітичному забезпеченню (IA3) виконання завдань військами під час повсякденної діяльності на цей час приділяється дедалі більше уваги. Ввпроваджена у практику інформаційнотелекомунікаційна система «Інформаційний портал Національної поліції України», система управління нарядами, у тому числі з використанням навігаційних систем, автоматизовані засоби з підтримання роботи посадових осіб штабу під час планування діяльності та ін.. Однак IАЗ підготовки та проведення спеціальних дій (операцій) не завжди відповідає сучасним вимогам.

Аналізуючи показники повноти, достовірності й оперативності інформації, що надходить від різних джерел у ході участі угруповань НГУ за призначенням під час забезпечення заходів в умовах надзвичайних ситуацій, можна зробити висновки про те, що на сьогодні не завжди IАЗ задовольняє головному показнику ефективності, який спрямований на якісне виконання завдань, усунення недоліків, вирішення існуючих проблем з урахуванням наявних сил і засобів та поліпшення остаточних результатів. У зв'язку з цим існує протиріччя між зростаючими потребами НГУ в інформації та нездатністю існуючої системи ІАЗ надати інформацію з необхідною якістю, що свідчить про актуальність пошуку шляхів адаптації структури та побудови системи IA3 відповідно до потреб інформаційно-аналітичного забезпечення угруповань НГУ при виконанні завдань за призначенням, особливо під час застосування військ в умовах надзвичайних ситуацій.

Аналіз останніх досліджень і публікацій. На сторінках наукових видань неодноразово розглядалися питання IA3 діяльності внутрішніх військ МВС України Національна гвардія України $є$ правонаступником цих формувань) [1] Безпосередньо, а саме удосконаленню системи інформаційноаналітичного забезпечення щодо прийняття рішення в надзвичайних ситуаціях присвячено дослідження О. Г. Барило [15].

У статтях і виданнях [2, с.7; 3, с.226; 4, с.7; 5, с.34] обгрунтовувалися сутність та складники інформаційного забезпечення, проводився аналіз основних проблем та пропонувалися деякі напрямки його вдосконалювання. Так, у виданнях [3, с.228; 6, с.42] викладені основні поняття, характеристики, 
структура та окремі напрямки розвитку інформаційного забезпечення процесів управління у процесі службово-бойової діяльності. У праці [2, с. 10] визначено особливості інформаційного забезпечення, проведено аналіз засобів і джерел отримання інформації та даних, які можна від них одержати. У статті [7, с. 9] запропоновано вдосконалення інформаційного забезпечення діяльності на підставі визначення соціальних і психологічних факторів, а у статті [8, с. 74] - напрямки вдосконалювання інформаційного забезпечення діяльності органів прокуратури України. Публікації [5, с. 34;9, с. 27; 10, с. 108] також присвячені питанням IA3 діяльності, зокрема: розглянуто існуючі тенденції щодо побудови системи IA3 правоохоронних органів під час виконання службово-бойових завдань 3 конвоювання, запропоновано підходи до отримання службової інформації, необхідної для управлінської діяльності; визначено вимоги до інформації, що підлягає аналізу в органах управління, проведено аналіз засобів і джерел отримання інформації та даних, які можна від них одержувати [11, с. 15]; запропоновано моделювання структури системи IA3, розглянуто основні підходи до побудови інформаційноаналітичної системи на основі ГІС-технологій [12, с. 23] .

Віддаючи належне вказаним вище та іншим науковим працям у цій сфері, зазначимо, що у питаннях стосовно розвитку інформаційно-аналітичного забезпечення НГУ під час підготовки та виконання службово-бойових завдань спільно з іншими правоохоронними органами, підтримки рішень, що приймаються, залишається чимало невирішених проблем, які потребують детального аналізу.

Мета статті. Розкрити підхід до побудови механізм інформаційноаналітичного забезпечення, яка відповідає вимогам необхідної повноти надходження інформації до відповідних органів управління НГУ при підготовці та у ході виконання завдань за призначення в умовах надзвичайних ситуацій, але не перевантажує їх.

Виклад основного матеріалу. Основна мета побудови механізму інформаційно-аналітичного забезпечення угруповання НГУ - забезпечити ефективне виконання службово-бойових завдань за призначенням у встановлені строки при мінімальних витратах сил та засобів. Для досягнення цієї мети необхідно створити систему інформаційно-аналітичного забезпечення, яка б являла собою сукупність розташованих на місцевості та функціонально й ієрархічно пов'язаних між собою органів управління, пунктів управління, засобів зв'язку і автоматизації, а також спеціальних засобів, які забезпечують збирання, моніторинг, оброблення, оперативний аналіз даних, перевірку достовірності та підготовку підсумкового донесення.

Здатність подібної інформаційно-аналітичної системи реалізувати покладені на неї функції, у свою чергу, залежить від структури цієї системи, під якою розуміється таке взаємне розташування і взаємозв'язок іiі елементів (органів управління, пунктів управління, засобів управління і зв'язку, об'єктів управління та інших джерел і споживачів інформації), що забезпечує цілісність цієї системи та іï функціональну придатність. Від структури інформаційно-аналітичної системи залежить эї можливість зберігати 
властивості у разі зовнішніх і внутрішніх змін умов їі функціонування [13, с. 119].

Отже, задача синтезу доцільної структури інформаційно-аналітичної системи формально зводиться до такого: знайти склад елементів системи (джерел i споживачів інформації) та інформаційні зв'язки між ними, реалізація яких дозволяє задовольнити встановлені вимоги до якості IA3 при виконанні завдань за призначенням у разі відомих ресурсних обмежень щодо реалізації системи [14, с. 10].

Як об'єкт синтезу інформаційна система розглядається, як відомий склад різноманітних джерел та споживачів інформації. Вони поєднуються між собою інформаційними зв'язками, які визначають шляхи поширення інформації у системі. До інформаційних процесів у такій системі належать ті, що пов'язані 3 добуванням, обробленням, передаванням, аналізом та використанням інформації для вирішення завдань у ході управління підрозділами. Основним завданням інформаційно-аналітичної системи $є$ забезпечення надання на всіх рівнях управління інформації про реальний стан оперативної обстановки, можливі напрямки iï розвитку, підготовка конкретних пропозицій щодо попередження та оперативного реагування на зміну обстановки, своєчасне надання інформації, яка задовольняє вимоги повноти даних та зведень, доведення та об’єктивна оцінка результатів виконання завдань за призначенням угрупованням НГУ. Функції системи реалізуються за допомогою засобів IA3, до яких відносять засоби збирання, передавання, оброблення, зберігання, аналізу та відображення інформації.

Методика, що пропонується авторами як механізм синтезу інформаційноаналітичного забезпечення, призначена для синтезу (пошуку) раціональної структури системи інформаційно-аналітичного забезпечення і має такі складові:

систему показників, гіпотез, припущень, що характеризують процеси IA3 [10, с. 110];

способи розрахунку значень зазначених показників [4, с. 7];

порядок синтезу варіантів структури системи IA3.

Вхідними даними для реалізації наведеної методики $є$ перелік інформаційних складових про обстановку, а також перелік і характеристики джерел та споживачів цієї інформації , що є елементами системи IA3.

Завдання синтезу раціональної структури полягає у знаходженні таких зв’язків між указаними елементами системи IA3, які забезпечують необхідну повноту надходження інформації до відповідних органів управління, але не перевантажують їх надлишковою.

Загальний порядок синтезу структури системи IA3 прийняття рішення наведений на рис. 1 і передбачає таке.

1. Введення вхідних даних (блок 1): перелік потрібних інформаційних складових даних про обстановку, дані про джерела та споживачів інформації, про зв'язки між ними. 


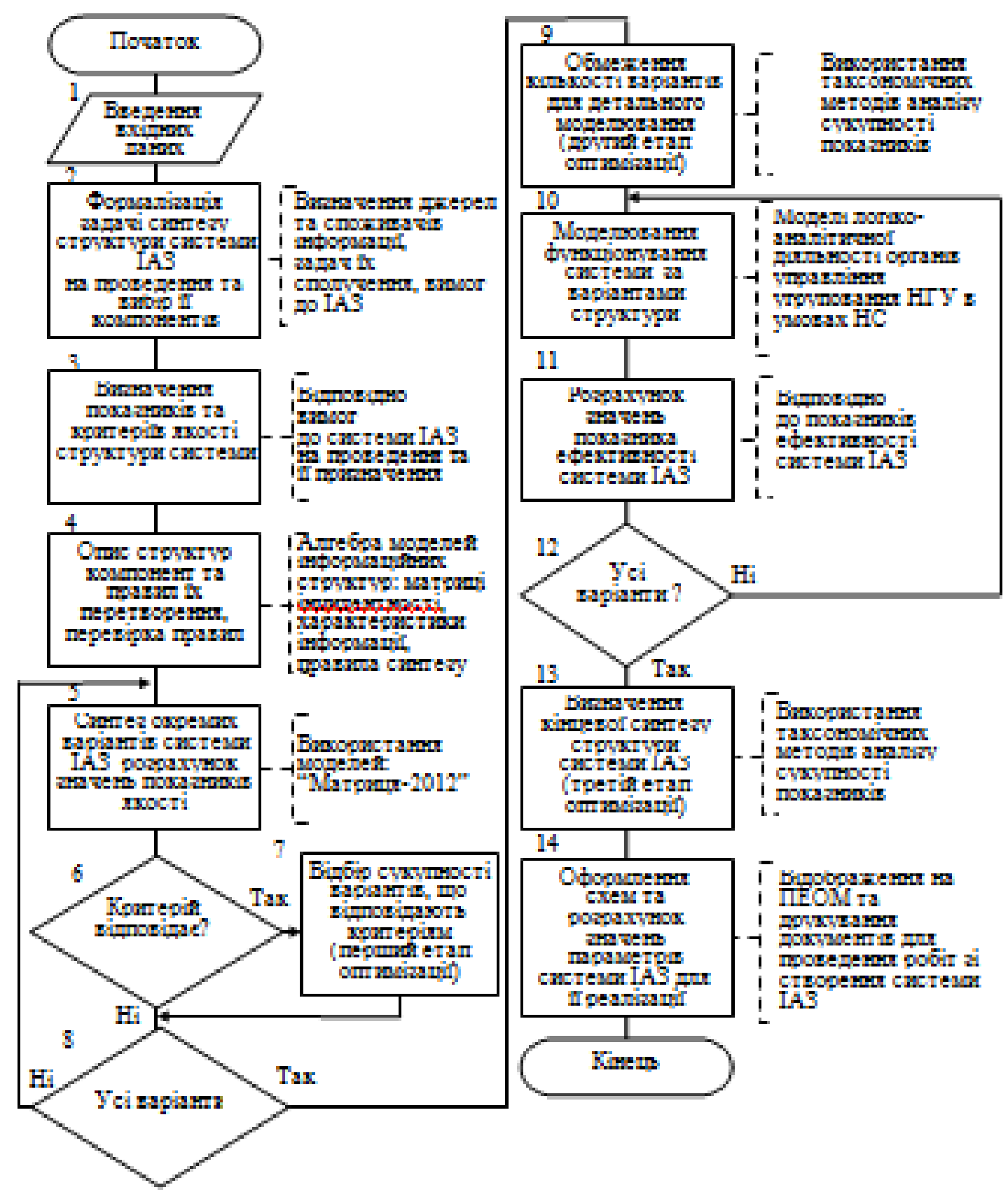

Рис. 1. Порядок синтезу раціональної структури системи інформаційноаналітичного забезпечення угруповання НГУ в умовах надзвичайного стану Джерело: розроблено авторами

2. Формалізацію задачі синтезу структури системи IA3 та вибір іiі компонентів (блок 2). Для вирішення цієї задачі використовується метод синтезу структури системи IA3 за допомогою алгебри моделей інформаційних структур $[14$, с. 9]. При цьому відповідно до потрібного вигляду інформаційно-аналітичної системи та вирішуваних завдань визначають перелік і характеристики джерел та споживачів інформації (вузлів оброблення інформації), задачі їх сполучення у єдину систему, характеристики інформаційних засобів, які $є$ (синтез структури 3 відомих конструктивних компонентів) або які потрібно мати (синтез структури 3 компонентів із завчасно заданими властивостями, наприклад, на етапі 
проектування системи та iі засобів). Визначають параметри можливих потоків інформації та продуктивність засобів пї передачі й оброблення. Формулюються вимоги до створюваної системи IАЗ. У результаті цих робіт формалізується задача синтезу структури системи IA3, а саме: 3 яких компонентів створювати систему, як їх поєднувати та які гіпотези i припущення висунуто до моделі структури інформаційної системи, щоб забезпечити іï відповідність оригіналу у рамках поставлених вимог та задач, що будуть вирішуватися із застосуванням інформаційної системи. На основі проведеного часткового аналізу визначається, чи є вирішення поставленої задачі синтезу інформаційно-аналітичної структури взагалі або які компоненти потрібно додати, щоб воно існувало. Позитивна відповідь на це питання є основою для переходу до виконання наступних робіт.

3. Визначення показників та критеріїв якості структури системи IA3 включає (блок 3) проведення аналізу висунутих вимог до структури, пошук показників, що відображують шукані властивості структури системи IA3 у рамках сформованих гіпотез та припущень, формування критеріїв, що дозволять відкидати непридатні варіанти структури системи IA3 .

4. Опис структур компонент інформаційно-аналітичної системи (внутрішньої структури джерел та споживачів інформації 3 точки зору проходження інформації, інформаційних взаємозв'язків між ними) та правил їх перетворення 3 використанням розроблених моделей інформаційних структур (блок 4). На цьому етапі формуються матриці інцидентності (моделі початкових структур), перетворення яких дозволить отримати шукану модель структури. Це, по суті, формалізація вхідних даних (операндів) для наступного синтезу структури. Далі, відповідно до поставленої задачі здійснюється пошук таких операторів у просторі моделювання, застосування яких до початкових операндів дозволяє побудувати (синтезувати) шукану структуру, що теж буде мати вигляд операнда алгебри моделей інформаційних структур. Сукупність операторів, знайдених відповідно до потрібних правил перетворення моделей інформаційних структур, описується мовою алгебри матриць інформаційних моделей та перевіряється на простих прикладах (для цього можна застосовувати розроблену модель “Матриця-2012”). У перспективі цей процес може бути автоматизований, але у будь-якому випадку він потребує втручання людини для контролю коректності переходу від оригіналу (структури інформаційно-аналітичної системи) до його моделі (опису структури системи IA3 та правил іiі перетворень).

5. Синтез окремих варіантів системи IA3 та розрахунок значень показників їх якості (блок 5). Вирішувана відповідно до блоків 4, 5 задача часткового синтезу дозволяє побудувати варіанти структур системи IA3 шляхом знаходження та застосування сукупності перетворень вхідних даних, які дозволяють отримати шукані моделі структури системи IA3. Проте кількість таких моделей може стати значною, що потребує пошуку серед них раціональної (тобто, по суті, вирішення задачі оптимізації структури). Тому відповідно до кожної знайденої моделі структури системи IA3 
розраховуються значення показників якості структури у синтезованому варіанті.

6. Перевірка того, чи відповідають синтезовані окремі структури системи IA3 (блок 6) визначеним критеріям (вимогам). На цьому етапі вирішуються задачі визначення еквівалентності знайдених варіантів структур (чи збігаються множини побудованих моделей структур системи IA3 між собою) та мінімізації кількості цих варіантів (відкидання моделей, еквівалентних у рамках визначених властивостей оригіналу, або тих, що не відповідають вибраним критеріям якості).

7. Відбір сукупності варіантів, що відповідають критеріям (блок 7). У результаті формується сукупність окремих (не еквівалентних) варіантів структур, що відповідають вибраним критеріям. Це перший етап оптимізації, що передбачає відкидання незадовільних варіантів структур та формування множини варіантів для подальшого пошуку раціональної структури системи IA3.

8. Перевірка умов закінчення перебору варіантів (блок 8). Клас структур системи IA3, що розглядається у рамках вирішуваної задачі, остаточний (кожна окрема структура має кінцеву розмірність, кількість таких структур також скінченна). Це дозволяє здійснити перебір різноманітних варіантів моделей структур у визначеному просторі моделювання. Якщо такий перебір не закінчено, то переходять до синтезу наступного варіанта структури (блок 5). Після закінчення перебору здійснюється перехід до наступного етапу методики.

9. Обмеження кількості варіантів для детального моделювання функціонування структури системи IАЗ у вибраних варіантах та проведення аналізу якості структур (блок 9). У зв’язку з тим, що кількість відібраних варіантів може виявитися значною, подальше детальне моделювання функціонування системи IA3 у всіх вибраних варіантах структур системи IA3 може зайняти неприпустимо великий час. Щоб цього не відбулося, кількість варіантів необхідно обмежити (наприклад, виходячи 3 наявного часу на проведення робіт та часу, що витрачається на оброблення даних по кожному окремому варіанту). Для цього рекомендовано використовувати таксономічний метод аналізу сукупності показників, що дозволяє вибрати задану кількість кращих у цьому розумінні варіантів 3 припустимих, що визначені на попередніх етапах робіт. По суті, це другий етап оптимізації (вибору раціональної) структури, що синтезується.

10. Моделювання функціонування системи IA3 за варіантами вибраних структур (блок 10). Для визначення раціонального варіанта структури системи IA3 з відібраних треба знайти той, який буде кращим в умовах реального застосування системи IA3. Це потребує проведення моделювання функціонування такої системи за варіантами вибраних структур

Для моделювання функціонування системи IA3, що використовується на етапі планування службово-бойових дій за призначенням, доцільно застосовувати відомі моделі логіко-аналітичної діяльності органів управління НГУ. 
11. Розрахунок значень показників ефективності системи IA3 за результатами моделювання (блок 11). Залежно від задач, які вирішуються за допомогою системи IA3, показники, що характеризують іï ефективність, можуть бути різними. Для системи IA3, що забезпечує управління угрупованням НГУ, як такий показник доцільно вибрати той, що характеризує очікуваний приріст ефективності службово-бойових дій угруповання НГУ, за рахунок реалізації системи IA3 у вибраному варіанті структури. Водночас безпосередньо визначити приріст ефективності за рахунок використання системи IA3 на етапі планування важко у зв'язку 3 невизначеністю низки факторів, що додатково впливають на результат службово-бойових дій. У цьому випадку зазвичай використовують гіпотезу про те, що своєчасно прийняте рішення, яке враховує більшу кількість значущих для виконання службово-бойового завдання факторів, апостеріорі дасть більший приріст ефективності дій частин та підрозділів НГУ. У разі прийняття такої гіпотези як показник ефективності системи IA3 стає можливим використовувати показник повноти IA3 прийняття рішення. Оцінюючи систему за критерієм “ефективність-вартість”, для визначення воєнно-економічного ефекту додатково необхідно розрахувати витрати на створення, утримання та застосування інформаційної системи. Результати розрахунків запам'ятаються для наступного використання.

12. Після перебору всіх варіантів (блок 12) здійснюється перехід до визначення шуканої раціональної структури системи IA3 .

13. Визначення кінцевої синтезованої структури системи ІАЗ (блок 13). Це третій (останній) етап оптимізації структури. Він стає потрібним у зв'язку 3 тим, що у результаті детального моделювання функціонування системи IA3 під час вирішення задач, для яких вона призначена, отримують додаткові дані щодо властивостей та ефективності такої системи. У загальному випадку кількість показників, що при цьому потрібно порівнювати для вибору раціонального варіанта, може стати великою. Тому на цьому етапі також використовується таксономічний метод аналізу сукупності показників. У результаті вибирається варіант синтезованої структури IA3, що буде раціональним з точки зору вибраної системи показників та критеріїв її якості.

14. Оформлення схем та розрахунок значень параметрів системи IA3 угруповання НГУ із синтезованою структурою (блок 14), підготовка пропозицій для іiі реалізації. Це кінцевий етап методики, на якому формуються вихідні дані, потрібні для реалізації вибраного варіанта системи IA3 .

Висновки та перспективи подальших досліджень. Таким чином, результатом застосування методики, як механізму синтезу інформаційноаналітичного забезпечення, є синтезована раціональна у шуканому сенсі структура системи ІАЗ угруповання НГУ при виконанні завдань за призначення в умовах надзвичайних ситуацій. У цій методиці застосовано метод синтезу структури інформаційно-аналітичної системи з використанням алгебри моделей інформаційних структур та таксономічний метод, що дає 
можливість визначити раціональний варіант структури системи IA3 серед усіх вибраних.

У результаті застосування такого механізму синтезу з'являється можливість створення обгрунтовано раціональної структури системи IA3 угруповання НГУ на виконання завдань за призначенням у випадках, коли за великої кількості елементів ці системи стають не придатними для проведення надійного аналізу їх структур іншими способами.

Напрямами подальшого дослідження є застосування такого механізму в умовах різних надзвичайних ситуацій.

\section{Лimepamypa:}

1. Про Національну гвардію України: Закон України від 13.03.2014 p. №876-ҮII // База даних Верховної ради України / BP. URL: https://zakon.rada.gov.ua/laws/show/87618\#Техt (дата звернення: 20.05.2020).

2. Довбня, В. В. Особливості інформаційного забезпечення у внутрішніх військах МВС України. Честь і закон. 2009. № 4. С. 4-12.

3. Використання інформаційних технологій та телекомунікаційних систем в процесі управління військами: навч. посібник. / Г. А. Дробаха та ін. Х.: Акад. ВВ МВС України, 2010. - 337 с.

4. Аналіз відповідності системи інформаційно-аналітичного забезпечення проведення силової фази спеціальної операції 3 припинення масових заворушень сучасним вимогам та шляхи ії вдосконалення/ Г. А.Дробаха та ін.. Збірник наукових праць Академії внутрімніх військ МВС України. Х.: Акад. ВВ МВС України, 2012. № 1. С. 4-12.

5. Протасенко, К. О. Інформаційне забезпечення діяльності внутрішніх військ та аналіз його основних проблем. Честь і закон. 2008. № 1. С. 32-35.

6. Мануїлов, С. В. Автоматизація управління військами, математичне та інформаційне забезпечення прийняття рішень у різних ланках управління внутрішніх військ МВС України. Честь $і$ закон. 2007.№ 2.С. 41-44.

7. Бєлай, С. В. Удосконалення інформаційного забезпечення службово-бойових дій внутрішніх військ на основі визначення соціальних та психологічних факторів динаміки натовпу. Збірник наукових пращь. Хмельницький: НАДПСУ, 2009. № 49. С. 7-10.

8. Куліш, А. Напрямки вдосконалення інформаційного забезпечення діяльності органів прокуратури України.Форум права. 2006. № 3.С. 72-76.

9. Єрмошин, М. О. Інформаційно-аналітичне забезпечення виконання службовобойових завдань 3 конвоювання. Честь $і$ закон. 2008. № 2. С. 25-30.

10. Розанова, Л. В. Моделювання структури системи інформаційно-аналітичного забезпечення прийняття рішень у військовій частині внутрішніх військ на проведення силової фази спеціальної операції з припинення масових заворушень. Честь $i$ закон. 2011. № 2. С. 106-113.

11. Довбня, В. В. Методи інформаційно-аналітичної роботи штабів при аналізі оперативної обстановки під час виконання завдань службово-бойової діяльності внутрішніх військ. Честь $і$ закон. 2008. № 1.С. 12-17.

12. Горєлишев, С. А., Побережний А.А., Сальников О.М. Принципи інтегрування геоінформаційної системи у структуру інформаційно-аналітичного забезпечення службово-бойової діяльності внутрішніх військ МВС Українит] Збірник наукових праць Академії внутрішніх військ МВС України.Х.: Акад. ВВ МВС України, 2011. Вип. 2.С. 20-24.

13. Городнов, В. П., Дробаха Г.А., Срмошин М.А. Моделювання бойових дій військ (сил) протиповітряної оборони та інформаційне забезпечення процесів управління ними (теорія, практика, історія розвитку): монографія Х.: Харк. військ. ун-т, 2004.409 с. 
14. Дробаха, Г. А., Смірнов С.Б., Топчій А.Г. Методичні підходи до вирішення задачі синтезу структур інформаційних та інформаційно-управляючих систем військового призначення] . Збірник наукових пращь. ХВУ.Х., 2004.Вип. 2 (49).С. 8-12.

15. Барило О.Г. Удосконалення системи інформаційно-аналітичного забезпечення щодо прийняття рішення в надзвичайних ситуаціях. Теорія та практика державного управління. 2018. Вип. 2. С. 212-219. URL: http://nbuv.gov.ua/UJRN/Tpdu_2018_2_34 (дата звернення 20.05.2020).

\section{References:}

1. Dovbnia, V. V. (2009). Osoblyvosti informatsiinoho zabezpechennia u vnutrishnikh viiskakh MVS Ukrainy [Features of information support in the internal troops of the Ministry of Internal Affairs of Ukraine]. Chest i zakon - Honor and law, 4, 4-12 [in Ukrainian].

2. Drobakha, H. A., Skrypniuk, S. I., Bashkatov, Ye. H., Rozanova, L. V., et al. (2010). Vykorystannia informatsiinykh tekhnolohii ta telekomunikatsiinykh system $\mathrm{v}$ protsesi upravlinnia viiskamy [The use of information technology and telecommunications systems in the management of troops]. Kharkiv: Akad. VV MVS Ukrainy [in Ukrainian].

3. Drobakha, H. A. Muzychuk, V. A., Klishyn, V. M., Rozanova, L. V. (2012). Analiz vidpovidnosti systemy informatsiino-analitychnoho zabezpechennia provedennia sylovoi fazy spetsialnoi operatsii z prypynennia masovykh zavorushen suchasnym vymoham ta shliakhy yii vdoskonalennia [Analysis of compliance of the system of information-analytical support of the power phase of a special operation to stop mass riots with modern requirements and ways to improve it]. Zbirnyk naukovykh prats Akademii vnutrishnikh viisk MVS Ukrainy - Collection of scientific works of the Academy of Internal Troops of the Ministry of Internal Affairs of Ukraine, 1, 4-12 [in Ukrainian].

4. Protasenko, K. O. (2008). Informatsiine zabezpechennia diialnosti vnutrishnikh viisk ta analiz yoho osnovnykh problem [Information support of internal troops and analysis of its main problems]. Chest i zakon - Honor and law, 1, 32-35 [in Ukrainian].

5. Manuilov, S. V. (2007). Avtomatyzatsiia upravlinnia viiskamy, matematychne ta informatsiine zabezpechennia pryiniattia rishen u riznykh lankakh upravlinnia vnutrishnikh viisk MVS Ukrainy [Automation of troops management, mathematical and information support for decision-making in various levels of management of internal troops of the Ministry of Internal Affairs of Ukraine]. Chest i zakon - Honor and law, 2, 41-44 [in Ukrainian].

6. Bielai, S. V. (2009). Udoskonalennia informatsiinoho zabezpechennia sluzhbovo-boiovykh dii vnutrishnikh viisk na osnovi vyznachennia sotsialnykh ta psykholohichnykh faktoriv dynamiky natovpu [Improvement of information support of service and combat operations of internal troops on the basis of definition of social and psychological factors of crowd dynamics]. Zbirnyk naukovykh prats - Collection of scientific works, 49, 7-10 [in Ukrainian].

7. Kulish, A. (2006). Napriamky vdoskonalennia informatsiinoho zabezpechennia diialnosti orhaniv prokuratury Ukrainy [Directions for improving the information support of the prosecutor's office of Ukraine]. Forum prava - Forum prava, 3, 72-76 [in Ukrainian].

8. Yermoshyn, M. O., Kyrylenko, V. A. (2008). Informatsiino-analitychne zabezpechennia vykonannia sluzhbovo-boiovykh zavdan z konvoiuvannia [Information and analytical support for the performance of service and combat tasks of convoying]. Chest i zakon - Honor and law, 2, 25-30 [in Ukrainian].

9. Rozanova, L. V. (2011). Modeliuvannia struktury systemy informatsiino-analitychnoho zabezpechennia pryiniattia rishen u viiskovii chastyni vnutrishnikh viisk na provedennia sylovoi fazy spetsialnoi operatsii $\mathrm{z}$ prypynennia masovykh zavorushen [Modeling the structure of the system of information and analytical support for decision-making in the military unit of the internal troops to conduct the power phase of a special operation to stop mass riots]. Chest i zakon - Honor and law, 2, 106113 [in Ukrainian].

10. Dovbnia, V. V. (2008). Metody informatsiino-analitychnoi roboty shtabiv pry analizi operatyvnoi obstanovky pid chas vykonannia zavdan sluzhbovo-boiovoi diialnosti vnutrishnikh viisk [Methods of information and analytical work of headquarters in the analysis of the operational situation during the performance of tasks of service and combat activities of internal troops]. Chest i zakon Honor and law, 1, 12-17 [in Ukrainian]. 
11. Horielyshev, S. A., Poberezhnyi, A. A., Salnykov, O. M. (2011). Pryntsypy intehruvannia heoinformatsiinoi systemy u strukturu informatsiino-analitychnoho zabezpechennia sluzhbovo-boiovoi diialnosti vnutrishnikh viisk MVS Ukrainy [Principles of integration of geoinformation system into the structure of information-analytical support of service and combat activities of internal troops of the Ministry of Internal Affairs of Ukraine]. Zbirnyk naukovykh prats Akademii vnutrishnikh viisk MVS Ukrainy - Collection scientific works of the Academy of Internal Troops of the Ministry of Internal Affairs of Ukraine, 2, 20-24 [in Ukrainian].

12. Horodnov, V. P., Drobakha, H. A., Yermoshyn, M. A. (2004). Modeliuvannia boiovykh dii viisk (syl) protypovitrianoi oborony ta informatsiine zabezpechennia protsesiv upravlinnia nymy (teoriia, praktyka, istoriia rozvytku) [Modeling of combat operations of troops (forces) of air defense and information support of management processes (theory, practice, history of development)]. Kharkiv: Khark. viisk. un-t [in Ukrainian].

13. Drobakha, H. A, Smirnov, Ye. B., Topchii, A. H. (2004). Metodychni pidkhody do vyrishennia zadachi syntezu struktur informatsiinykh ta informatsiino-upravliaiuchykh system viiskovoho pryznachennia [Methodical approaches to solving the problem of synthesis of structures of information and information-control systems of military purpose]. Zbirnyk naukovykh prats / KhVU - Scientific Works of Kharkiv National Air Force University, 2(49), 8-12 [in Ukrainian]. 